\title{
Diffuse anxieties, deprived entrepreneurs: Commission reform and middle management
}

\author{
Michael W. Bauer
}

\begin{abstract}
There is consensus that the Kinnock reform changed the European Commission considerably. However, scholars have focused mainly on describing the process, content, and scope of the reform. There is as yet little empirical research about the effects this reform may have. This paper puts forward an argument as regards the link between reform effects and policy output. In order to do so, it focuses on the new role of middle management, i.e. the heads of unit. A survey of more than 100 heads of unit of policy-making Directorates-General serves as the empirical basis. The data indicate a substantial ambiguity of the heads of unit towards recent organizational change. As a consequence of the reform, the Commission will probably become more inward-looking and previously crucial policy entrepreneurs will have less time and other resources for advocating policy content than in the past.
\end{abstract}

KEY WORDS Administrative reform; European Commission; middle management; policy drafting; policy entrepreneur; policy output.

\section{INTRODUCTION}

Despite more than five decades in existence, the European Commission has engaged only recently in reforming its administration. This reform has been the subject of a number of insightful studies (Kassim 2004a, 2004b; Cini 2004; Levy 2004, 2006; Stevens and Stevens 2006; Spence and Stevens 2006; Balint et al. 2008). Apart from the intriguing question of why, given the new public management prominence of public sector reform in most of its national constituencies, the Commission was able to resist modernization for such a long time (Bauer 2007), scholars have been primarily occupied with describing the process as well as the content of the modernization, and assessing the internal consistency of individual reform chapters. In other words, the dependent variables have been primarily timing, implementation, substance and scope of the modernization of the Commission. Yet, since the reform has been in effect for some time, the challenge is increasingly to discover what difference, if 
any, it actually makes. More precisely, one wonders what effects the reform has on the role of the European Commission as an actor within European public policymaking and, given the centrality of that organization for the EU system of governance, eventually therefore on EU policy output. Otherwise, why should one keep bothering - outside the small circle of EU public administration scholars about the recent reform of the Commission?

In this article I attempt to tackle this effect question, hence turning the reform issue more towards the independent variable side of the story. The evidence presented will underline why one should perhaps bother more about the recent organizational change inside the Commission with regard to policy output. I will probably raise more questions than I am able to answer. Basically I argue that the reform, although in itself perhaps really an "historic accomplishment' and 'heroic task' (Kassim 2004a, 2004b), will seriously change and eventually limit the capability of the Commission to deliver policy and to shepherd its legislative drafts through the formal and informal stages of the EU policy process (Nugent 2001: 242) - at least to the standard as we know it.

To substantiate this claim, I will make two assumptions. The first is to centre this analysis upon the 'middle management' - usually the heads of unit (HoU) - inside the Commission. Neither the rank and file nor the top managers but the $\mathrm{HoU}$ are - in intellectual and administrative terms - the organizational backbone of the Commission. It is in the person of an HoU that policy expertise usually culminates and interlinks with the politics stream of EU public policymaking (Kingdon 1995; Richardson 2006). Below the HoU, individual power is too weak; above the $\mathrm{HoU}$ top managers - i.e. directors and directors-general - are too busy to engage intensively in the minutiae of an individual dossier while taking into account the various national and societal positions to identify viable lines of a satisfactory political compromise.

The second assumption is to qualify the dominant view that sees the Commission's strength in agenda-setting. There is a broad consensus that the Commission's (and the European Union's (EU's)) role is much more significant in the early stages of the policy process than in later ones (Peters 1994, 1996; Bauer 2006). Given the growing importance of the presidency, the European Parliament, European-level lobbying and the usual contingencies of the modern policy process, the Commission's right of initiative constitutes in my view - in the first place a drafting rather than an agenda-setting power. Delivering concrete policy drafts, however, is usually the prime task of the HoU.

I will proceed as follows. In the next section I review the literature on the Commission which is relevant to the research question presented here - in order to show that my assumptions are plausible. I will then recall the content of the Kinnock reform (section 3). This can be done briefly since I can draw on existing work and on those aspects of importance for the issues raised here. Section 4, the main section, reports on the results of a survey showing the misgivings and anxieties of middle managers as regards the general thrust of the reform, but also the endorsement of particular elements of the management 
change. The article ends with a short conclusion summarizing the main implications of the results for the Commission's future role in EU policymaking. In a nutshell, I conclude that the recent reform of the Commission does indeed comprehensively redefine the role of the HoU. The resource base (of the position) of a HoU to focus on policy drafting is hugely reduced. Negative consequences for the organization's potential to deliver a policy draft of high quality are therefore very likely.

\section{THE ROLE OF THE COMMISSION IN EU POLICY-MAKING}

The literature on the Commission fills libraries and is certainly too diverse to be summarized here (but see Cini 1996; Nugent 1997, 2001; Spence 2006; Bauer 2005). Beyond the debate about the Commission's autonomous capacity as a supranational actor inclined to influence the systemic development of regional integration according to its own preference (Smyrl 1998; Moravcsik 1998; Pollack 2003), it is probably fair to say that comparative policy analysis and public administration scholars have recently been most active and (arguably) most successful in coming to grips with this actor and its role in multi-level policy-making.

In my view, there is a broad consensus within the public policy and administration community that the Commission's strength lies rather in the early stages of the policy cycle (from problem definition up to, say, decisiontaking) than in (supervising) policy execution and delivery (Bauer 2006). The concepts developed in this regard are agenda-setter, policy entrepreneur and subterfuge (Cram 1993; Peters 1994; Héritier 1997; Sabatier 1993).

Analysts usually treat the Commission (or an individual Directorate-General (DG) or service within it) as an actor itself, but they rarely specify under what conditions entrepreneurship - to take the most usual notion that conceptualizes the Commission as a purposeful political actor able to pursue an aim over long time periods and via astonishing detours - actually works inside the Commission administration. In this context it is perhaps useful to recall that the substantial competence behind entrepreneurship is the Commission's power of initiative, i.e. its monopoly to propose policy drafts. The EU may be an 'agenda-setting paradise' (Peters 1994: 21; Rochefort and Cobb 1995) with the Presidency, Council, and Parliament constantly advancing (to the detriment of the Commission) their agenda-setting powers. However, in the end it is the Commission that delivers the policy draft and therefore sets the outlines for political compromise, i.e. where the final decision inside and between Council and Parliament may come to lie (Coombes 1970; Noel 1973; Peterson 1995; Cini 1996; Hix 2005). The crucial questions - which in my opinion have up to now not received their due attention - then become $w h o$ are the entrepreneurs inside the Commission and how does this entrepreneurship actually work? In the following I will concentrate on the motivational and administrative implications of these questions. 
Inside the Commission, reinforced through respective patterns of advancement and promotion, the noblest tasks have always been in conceiving new projects and pushing forward new initiatives for further integration (Hooghe 2001: 156). Consolidation, administration and management of tasks and initiatives already achieved are thought to be of secondary value (Ludlow 1991; Spence 2000; Bauer 2002). Moreover, in this fragmented and heterogeneous administration (Christiansen 2006), the individual level plays the crucial role. The aim is to get one's own proposal 'through' - or at least to gain 'visibility' with superiors by trying hard. In the end, successful policy drafts are the currency of prestige and the 'capital' that returns in terms of career advancement, resource expansion or obtaining other interesting dossiers. Successful drafts reflect on the Commissioner in charge, the director-general, the director and down the line of organizational hierarchy. However, policy formulation is a genuinely individualistic task (Peters 1996:21). It is usually done at unit or section level guided by the respective HoU. The HoU occupies the pivotal position. As regards content, he used to be the acknowledged expert. At the same time he is an experienced insider who knows the Commission machinery, the informal side of the organizational hierarchy and the crucial policy pundits within the other European institutions, national administrations or relevant lobbies. The very fragmentation of the Commission and the deficient horizontal and vertical co-ordination mechanisms reinforce the HoU's role and importance. In practice it is the rule rather than the exception that the sensible task of policy drafting lies in the hands of a single HoU as the central Commission official (Peters 1994: 16). That trend as I would call it - of the individualization of policy formulation has not gone unnoticed. Other scholars have referred to it as the 'dossier' or the 'rapporteur' approach.

This dossier approach is a way of working within the Commission that underpins much of the day-to-day life of officials, to the extent that it is taken for granted by those that have been socialised into Commission practice. The approach is essentially a juridical one, resting on the notion of individual responsibility for specific cases and on the technocratic expertise of officials who tend to become immersed in one small area of policy, becoming indeed experts in their own right.

(Cini 1996: 153)

Neill Nugent describes the process of policy drafting, as it usually advances within the responsible DG, as even more pronounced:

[Usually] a head of unit... assumes responsibility for what is known as a dossier (file) on the proposal. This involves preparing the proposal and shepherding it through its decision-making stages. In working on the drafting of the proposal this official - known as the rapporteur - has an absolutely crucial task since the legislation that is eventually adopted is likely to contain most of what is in the Commission's draft.

(Nugent 2001: 242) 
Hence, the rapporteur - usually the HoU - is in many respects the central individual behind a Commission legislative proposal. The $\mathrm{HoU}$ is crucially located between technical expertise and political management. He is the one who maintains the contact between his expert team and the increasingly politicized actors hierarchically above as well as within the specific expert community outside the Commission. The importance of the HoU in identifying potential for (technical) consensus and for the time-consuming and challenging task of guiding the proposal through the formalities and informalities of the Commission's internal decision-making process can hardly be exaggerated (Nugent 2001).

In sum, the entrepreneurship of the Commission has an individualistic basis which up to now has been somewhat - though, as the quotations above show, not completely - neglected. As a starting point, this individualistic basis of Commission entrepreneurship is in my opinion best conceptualized in terms of motivation and administration. The motivational side of the story refers to the congruence of interests between the individual and the organization, i.e. getting policy drafts positively decided upon, fostered by the standard incentives of career perspectives, quality improvement of future responsibilities (getting the high potential 'dossiers') or acquisition of other office-maximizing resources. Unpacking the Commission as a public administration in this respect puts the $\mathrm{HoU}$ centre stage. From the perspective of analysing the effects of the recent Commission reform on policy output, the crucial question thus becomes whether and how the Kinnock reform modifies the position of the HoU, thereby affecting the Commission's entrepreneurship capacity.

\section{THE KINNOCK REFORM AND MIDDLE MANAGEMENT}

The substance, scope and timing of the recent administrative reforms of the European Commission have been extensively dealt with elsewhere (Kassim 2008, 2004a, 2004b; Metcalfe 2000; Bearfield 2004; Levy 2006). In this section it is thus unnecessary to go into detail. Instead, I would like to focus on two crucial aspects: the 'strategic planning and programming' and 'personnel policy' chapters of the reform. Both are not only regarded as most important, but also impact heavily on the HoU.

The chapter on Strategic Planning and Programming (SPP) is a cornerstone of the reform project. The traditional - Weberian - way of administrating was to be replaced by strategic priority-setting (on the basis of updated information about what is exactly done in the Commission and by whom), respective resource allocation, process monitoring, evaluation and - inherently connected - redistribution of financial and personnel resources on the basis of that programming cycle. One should note that activity-based cost management (Cokins 1996) is still output-focused rather than outcome-focused. But it is a far cry from the input steering that the Commission applied in the past. The SPP cycle has run since 2003 and has put policy priorities at the heart of the decision-making. .. Managers are required to focus on the need to deliver on priority objectives and to report on achievements and performance' (European 
Commission 2004: 6). The SPP cycle is indeed a challenge. Means and needs have to be justified in the light of targeted objectives. A detailed Annual Policy Strategy (APS) is drafted, discussed and agreed upon, involving virtually all layers of the internal administration in a huge communication and coordination exercise. The APS is translated into mission statements and work programmes for each Commission service, setting out specific objectives for directorates and units. In response Annual Activity Reports are required by each DG or service, which include strategic evaluations of activities and expenditure, and so on, up and down the hierarchy (Kassim 2004a: 48). Writing proposals for policy objectives, conceiving (measurable) progress and quality indicators, conducting impact assessment exercises, suggesting priorities, drafting respective reports, evaluating and communicating decisions to the rank and file have become the bread and butter of the HoU's daily job.

The personnel chapter was the second centrepiece of the modernization blueprint since budgeting, programming and co-ordination aspects have personnel implications, and vice versa. The linearization of careers and the new pension regime were among the most contested issues among staff unions, the reformers surrounding Kinnock and the representatives of the member states (Kassim 2004a, 2004b; Bauer 2007). The aims were to keep staff motivated until very late in their individual careers (more but smaller promotion steps) and to keep the costs of salaries and pensions in check. The hotly discussed money and motivation issues distracted perhaps from the fact that the core of the managerial side of the new personnel strategy was a kind of extended leadership role for the HoU. According to the new personnel concept, it is the $\mathrm{HoU}$ who has to instruct, supervise and guide his unit staff so as to fit the human resource variable to the equation of the new priority-setting, programming and co-ordination approach. The aim was to make the Commission administration more accountable to the political College of Commissioners. In this sense the role of the $\mathrm{HoU}$ in motivating, managing and guiding staff is pivotal. A particularly difficult undertaking turned out to be the distribution of assessment 'points'. Once an individual has accumulated a certain number of points, promotion becomes automatic. The distribution of points is an annual exercise and a highly competitive one, since the overall number of points is restricted. Some of these points are assigned by the directors-general, but the HoU distributes most of them. ${ }^{1}$ At any rate, it is the HoU who 'implements' the personnel strategy. He has to set annual job targets against which individual performance is assessed; he has to evaluate performance, and justify and report on his opinion; he has to negotiate the points, defend decisions, deal with more or less satisfied managers, and so on. As an $\mathrm{HoU}$ who experienced the reform effects underlined: "The HoU are now much busier with administrative stuff that comes with the reform. Personnel management things especially have been easier in the past. The reform has increased the responsibilities of the $\mathrm{HoU}$ substantially.' ${ }^{2}$ A Commission official working in the team that conceived and implemented the reform put it somewhat more baldly: 'In the past you became HoU for writing good policy papers. 
There was little interest in whether you were good at managing and guiding your team. ${ }^{3}$

All in all, the pressure on the HoU to develop and use staff potential in an optimal way - as defined by the SPP cycle - has increased dramatically. The good news is that HoU have gained in direct power over their personnel but the bad news is:

that power over personnel comes with high bureaucratic costs and greater responsibilities as regards internal administration. Time for participating in working groups, circulating policy papers and engaging in negotiations is gone. In this sense, the reform means more management and in certain respects also more bureaucracy for the HoU. The point is that the traditional approach that the best policy expert should become $\mathrm{HoU}$ is still very much alive in the heads of the people. Especially in the Commission, the HoU are usually motivated by the content side of their job. Most of them are kind of 'political criminals' ${ }^{4}$ in an absolute positive sense; meaning highly motivated experts in their policy fields who would just give anything for their dossier ... The reform means cultural change and that will take time. ${ }^{5}$

If the Kinnock reform thus utterly changes the role of the HoU, the obvious research question is how the HoU themselves assess the Kinnock reform with respect to their daily working life. To answer this question I conducted a survey whose results are presented below.

\section{SURVEYING MIDDLE MANAGEMENT}

In April 2007 the Commission employed 23,043 formal staff. According to internal sources, there are roughly $1,200 \mathrm{HoU}$, but only 800 have exclusively policy tasks. I used the information available from the organizational charts of the 13 DGs indicated by the Commission itself as policy DGs (e.g. those for agriculture, cohesion, environment, etc.) in order to create a list of $\mathrm{HoU}$ who are clearly engaged in policy-making. From this general population I randomly selected 200 as my survey population. In addition I also sampled some directors and directors-general as a control group. One hundred and sixteen telephone interviews with policy $\mathrm{HoU}$ were completed, a response rate of 58 per cent.

Almost 60 per cent said that the position of $\mathrm{HoU}$ had experienced the most dramatic changes in its profile owing to the Kinnock reform. The directorsgeneral came second with 20 per cent. In the same vein and somewhat astonishingly - in respect of the short time span since the reform had been in operation - asked about the effects of the Kinnock reform with regard to their individual promotion, one-sixth of the HoU already saw an impact, shared equally between positive and negative.

Enabling the Commission to redistribute resources quickly and in accordance with changing priorities was a major concern for the reformer. Clearly, if this redistribution is only marginal it is questionable whether it pays to install 
new, painstaking, time-consuming and complicated procedures in the first place: policy ends would not change and neither would the distribution of means. The data put a big question mark over this crucial aspect. Asked about whether, as an outcome of the Kinnock reform, there had been a redeployment of personnel or financial resources because of changing political priorities, only a third of HoU saw such a redistribution while two-thirds did not see any.

As regards work profile, roughly 30 per cent of HoU considered 'promoting policies' as their top priority, followed by providing internal management leadership (25 per cent), supervising implementation (16 per cent) and generating ideas (10 per cent). Two equally ingrained 'camps' could be identified: leadership and implementation, on the one hand, and promoting policies and ideas, on the other. But saying what is the 'most important aspect of your work' as in the previous question is one thing, saying what the HoU really value most is something else. Asked whether the brightest policy innovators, irrespective of their level of seniority, should get more scope (and better career prospects) or whether fast-track, special arrangements for a small number of people should be avoided, two-thrids of the HoU replied that they would like to see more space given to the policy innovators, while only one-sixth objected.

The HoU were asked to assess 'the impact of the recent internal modernization (i.e. the so-called Kinnock reforms) in the light of their own experience' by agreeing (or not) with seven statements ('agree', 'disagree', or 'don't know'). All the statements were taken from the Commission's own documents (White Paper and progress reports) on the reform. The overall assessment of the reform effects was negative. With the statement 'My unit/service has become more efficient and effective' 59 per cent explicitly disagreed, and 15 per cent said they did not know (which is equally negative from the perspective of reform promoters). 'Personnel management has become leaner and more focused. I can concentrate more on the really important issues' was contested by 86 per cent of the HoU. With 'The orders/instructions from superiors have become clearer, more transparent and more coherent' 63 per cent disagreed, 12 per cent did not know. Similarly, little support can be found for 'I can work more autonomously because I can decide myself about important issues concerning the distribution of internal resources'; 71 per cent disagreed, 12 per cent did not know. However, with the statement "The new tools and rules are applied in a formal and superficial way. The majority of colleagues have yet to be convinced of their advantages' 72 per cent explicitly agreed. The excuse offered by the following statement, i.e. that it is still too early to tell, was rejected by a huge majority. The phrase went "The new tools and rules have yet to be applied coherently. Therefore, I do not have sufficient information to draw conclusions.' Fifty-five per cent disagreed, 29 per cent agreed, while 13 per cent did not know. At last the statement 'The new tools and rules do lead to more red tape and increase the internal administrative load' elicited very clear reactions as 88 per cent of the $\mathrm{HoU}$ unambiguously agreed. In other words, the $\mathrm{HoU}$ think that their units have not become more efficient, personnel management 
has in their eyes become painstaking, and instructions from superiors appear to be barely transparent. In sum, there seems to be little behind the rhetoric of increasing the autonomy of lower levels, and there is consensus that red tape has rocketed as a consequence of the Kinnock reform.

The picture brightened when the $\mathrm{HoU}$ were asked about specific managerial elements introduced by the reform in the sphere of strategic planning and programming and the new personnel policy. Roughly, there was a persistent quarter of HoU who saw the reform elements negatively but - in stark contrast to the previous questions - now frequently relative and sometimes absolute majorities assessed the changes positively. As regards strategic programming in particular, reporting schemes and prospective management planning met with the approval of an absolute majority of HoU. They appeared to approve especially of the new rules allowing them to define the responsibility of personnel individually and in advance. However, the setting of negative priorities was obviously seen as problematic. See Tables 1 and 2 for an overview.

$\mathrm{HoU}$ perceive the new personnel management even more positively than strategic programming. Ostensibly, they welcome the need to formulate detailed job descriptions, i.e. setting work-related personal targets and objectives. They are in favour of annual appraisal exercises and appreciate their power to decide on staff requirements and the related allocation of responsibilities. But they appear reluctant about the duties of leadership concerning (sometimes painful) decisions about the pay and promotion of their direct subordinates.

Finally, the survey included an open question. Out of $116 \mathrm{HoU} 50$ made sometimes lengthy - use of this last question to comment on the Kinnock reform. I coded these comments according to whether they indicated a positive, negative or neutral attitude towards the effect of the reform. Six were outright

Table 1 Strategic planning and programming: Which of the following elements improved your personal capacity to do your job? ${ }^{6}$

\begin{tabular}{lcccc}
\hline & $\begin{array}{c}\text { Negative } \\
(\%)\end{array}$ & $\begin{array}{c}\text { Positive } \\
(\%)\end{array}$ & $\begin{array}{c}\text { Irrelevant } \\
(\%)\end{array}$ & $\begin{array}{c}\text { Don't know } \\
(\%)\end{array}$ \\
\hline $\begin{array}{l}\text { Drafting the Annual Activity } \\
\quad \text { Report }\end{array}$ & 34 & 40 & 24 & 2 \\
$\begin{array}{l}\text { Preparing the Annual Strategy } \\
\quad \text { Decision }\end{array}$ & 32 & 46 & 20 & 2 \\
$\begin{array}{l}\text { Drafting the DG Annual } \\
\quad \text { Management Plan }\end{array}$ & 29 & 55 & 14 & 2 \\
$\begin{array}{l}\text { Interim evaluation and monitoring } \\
\quad \text { of achievements }\end{array}$ & 24 & 50 & 23 & 3 \\
$\begin{array}{l}\text { Defining the responsibilities of } \\
\quad \text { individuals }\end{array}$ & 11 & 63 & 20 & 6 \\
$\begin{array}{l}\text { Setting negative priorities } \\
\text { New reporting duties }\end{array}$ & 37 & 27 & 32 & 4 \\
\hline
\end{tabular}


Table 2 Personnel management: Which of the following elements of personnel modernization improved your capacity to do your job?

\begin{tabular}{lcccc}
\hline & $\begin{array}{c}\text { Negative } \\
(\%)\end{array}$ & $\begin{array}{c}\text { Positive } \\
(\%)\end{array}$ & $\begin{array}{c}\text { Irrelevant } \\
(\%)\end{array}$ & $\begin{array}{c}\text { Don't know } \\
(\%)\end{array}$ \\
\hline $\begin{array}{l}\text { Detailed job descriptions } \\
\text { Annual appraisal exercises }\end{array}$ & 13 & 73 & 13 & 1 \\
$\begin{array}{l}\text { Setting work-related and personal } \\
\quad \text { targets }\end{array}$ & 13 & 68 & 17 & 2 \\
$\begin{array}{l}\text { Deciding on staff requirements and } \\
\quad \text { allocation of responsibilities }\end{array}$ & 21 & 45 & 30 & 2 \\
$\begin{array}{l}\text { Promotion procedures } \\
\text { Setting objectives within your unit } \\
\text { Overseeing and assessing }\end{array}$ & 11 & 74 & 12 & 2 \\
$\quad$ achievements & 20 & 52 & 27 & 2 \\
Reducing function groups and & & & & \\
$\quad$ having a single pay scale with & 36 & 20 & 40 & 5 \\
$\quad$ 16 grades & & & & \\
\hline
\end{tabular}

positive (somewhere along the lines of 'management should be a time-consuming activity' or 'it was time for reform'), and another six were neutral (in the sense of 'esprit est bon, la mise en oeuvre moins car elle crée un surplus de la bureaucratie ... parfois amène à la diminution de l'effectivité'). The vast majority of the HoU agreed that some kind of management reform of the Commission administration had been overdue. But 38 took the opportunity to convey a clear message: 'the Kinnock reform can be summarized in one word: bureaucracy'. One of the more friendly comments in that category was 'many HoU feel they have to carry the heavy burden of bureaucratic, ineffective procedures that were introduced.' Others were sharper: 'Kinnock is a disaster and a 300 per cent bureaucracy increase with form accounting for 80 per cent and substance just for 20 per cent', it is 'paperwork that nobody reads' or just 'unproductive paper work'. Others talk about 'control mania' inside the Commission which 'creates a culture of fear'; 'control should be on a reasonable level: now it has gone mad'. Many statements reflect the fear that the Commission has lost its 'political duties', 'political priorities', 'political function' and that the 'original mission is forgotten'. The 'real problem is that process has become an aim in itself; there are 'lots of words, declarations, announcements which lead to nowhere; there is no increase in productivity'. In the same vein: 'productivity is decreasing, internal procedures are the biggest constraints'; 'What has been done is a castration! Bureaucracy and security measures kill all the potential productivity'. Or, with regard to the changing role of the HoU of major interest for my argument: 'avant les chefs d'unité étaient les experts du domaine, maintenant ils ne sont que des "managers"'. The point is that staff who were happy to have been reformed would probably have made different 
remarks. Considering the fact that the survey question did not directly invite comment on the deficiencies of the Kinnock reform, this becomes even more worrisome. ${ }^{7}$ The question was neutral: 'Do you wish to make a general or specific remark about the issues touched on in the survey?' Therefore, politicians and managers at the top of the Commission are well advised to take such strong reactions from their middle management seriously.

Apart from this descriptive evidence, I conducted some simple regressions in order to test standard hypotheses - taken from Hooghe (2001) - which could be invoked to explain why an individual HoU supports or rejects administrative reform. ${ }^{8}$ In other words, I took the expression of empathy or distaste of the $\mathrm{HoU}$ for the Kinnock reform as the dependent variable. Admittedly, Hooghe does not ask exactly the same research question as I do here. However, she investigates a number of mechanisms which may also hold analytical leverage in explaining the attitude of middle managers towards the recent reform of the European Commission, since she attempts to explain variance in the attitudes of managers as to whether they prefer a more managerial or a more politicalentrepreneurial Commission. Arguably, this cleavage also lies at the heart of the relationship between middle management and Commission reform as discussed in this paper. I present the results in Table 3. ${ }^{9}$

Only with regard to the academic background hypothesis, i.e. that reform empathy correlates positively with an educational background in economics, do I find the expected relationship (though with a very low level of significance). The hypothesis that those HoU from a country with a 'continental'

Table 3 Regression results

Sub-dimension

Dependent variable

Additive index Inkin_positive

Reform aversion of initiative-oriented DG

$-0.087(0.84)$

Reform aversion from idealist for European

$0.128(1.35)$ integration

Reform empathy owing to economic background

Reform aversion of managers close to retirement

$0.002(1.81)^{*}$

$-0.001(1.14)$

Reform empathy/aversion as function of public

$0.029(0.58)$

management reform intensity in home country

Reform empathy owing to work experience

within private sector

Reform aversion because of huge staff responsibility

Reform aversion owing to leftist political conviction

$0.000(0.14)$

Constant

$1.141(5.24)^{* *}$

Number of observations

116

R-squared

0.18

Note: Absolute value of $t$ statistics in parentheses.

* signific ant at 10 per cent ${ }^{* *}$ signific ant at 1 per cent. 
administrative culture (as opposed to countries full-heartedly embracing new public management reforms) also shows a correlation. However, the nexus goes in the opposite direction. Those HoU from a country with a low tendency to implement new public management change think more positively about the Kinnock reform than those from a country with an outspoken new public management background. Also, I find an unexpected correlation between time to retirement and assessment of the Kinnock reform. The logic is that younger and still ambitious $\mathrm{HoU}$, who know they will have to 'live' with the new rules of the game brought about by the reform, will be more accepting, while those 'who have nothing to lose', i.e. those whose careers will not be affected by the changes, can afford to be critical. Therefore, the closer to retirement a $\mathrm{HoU}$ is, the more openly critical he may be as regards his attitude towards the Kinnock reform. However, managers close to retirement are more positive about the recent changes than young managers. Interestingly, Hooghe found the same negative correlations in her data (2001: $163 \mathrm{ff}$.). The remaining hypotheses show no correlation pattern.

In sum, the survey results underpin the fact that the role of the HoU within the organization has been redefined by the recent administrative reform. At the very least, the results indicate huge feelings of anxiety, and sometimes even alienation, in their professional self-understanding as regards the effects of the Kinnock reform. According to the HoU, the general reform aims have not been met. What characterizes the current situation is an insufficient redistribution of resources, heavy red tape and heavy planning burdens, but not more autonomy. More specifically, the particular instruments introduced by the Kinnock reform - job descriptions, defining individual responsibilities, setting individual targets, annual appraisal exercises, systematically assessing achievements, monitoring and reporting duties - are evaluated more kindly, at times even very positively. This indicates a worrying level of alienation. The majority of HoU have misgivings about the reform and, more importantly, they dislike the new roles which the reform has assigned to them. Two-thirds still seem to prefer a role model as policy innovator and not one as public manager. However, as good public servants they accept their fate, and endorse in particular those reform elements which improve their capacity to do a proper job. In other words, they make an effort to function like managers, but in their hearts they still feel like policy entrepreneurs.

\section{CONCLUSION: BETTER MANAGERS, DEPRIVED ENTREPRENEURS}

Management reforms in the public sector (and elsewhere) usually have various effects - some may be intended, others unintended (Pollitt and Bouckaert 2004). In this article I attempted to gauge the possible implications of the recent Commission reform for EU policy-making. I assumed that the HoU, i.e. the middle management inside the Commission, is the crucial link 
between expertise and politics. And, further, I took for granted that the Commission's strength as an actor in EU public policy-making rests, to a large extent, on its ability to deliver concrete and substantial policy drafts of a high quality. From that perspective, I tried to find out what the recent Kinnock reform meant for the HoU. As it turned out, the Kinnock reform completely transforms the role of the HoU. It is probably not an exaggeration to think of the new role of the HoU as the centrepiece of the Kinnock strategy. This new role is displayed in the effort to make the Commission administration more accountable to the College, i.e. to subject policy output to central prioritysetting and to increase the capacities at the organizational top for political steering. Taken together, this reflects the usual new public management agenda of public sector reform (Bearfield 2004; Schön-Quinlivan 2008). Note that I do not make any claims about the appropriateness or, indeed, about the longterm chances of success of the Kinnock reform to change the Commission administrative culture in that perspective (cf. Balint et al. 2008). Actually and paradoxically, in this respect the Kinnock reform may well work and reform advocates are probably correct in pointing out that modernization is, after all, a long-term endeavour, and that it is therefore too early to tell whether or not it is successful. However, from the point of view adopted as the analytical focus for this paper, better internal management does not mean improved organizational capability for policy entrepreneurship. To be clear: I have not investigated policy results and I did not develop a theory or an analytical framework, let alone apply it to empirical testing, which could lead to the conclusion that EU public policy output decreased in quantity or declined in quality since the adoption of the Kinnock reform. These are questions I would recommend researchers to engage in. However, I do claim that the role of the Commission administration in the complicated equation of EU policy-making is weakened by the Kinnock reform. The Commission will become more inward-looking, and crucial individuals will have less time for policy content than they used to have in the past. In a seminal article from 1997, Brigid Laffan saw the challenge for the Commission to change from a policy entrepreneur to a programme manager. The new challenge after the Kinnock reform may be to maintain decentralized entrepreneurship capability at the policy level in an organization subjected to burdensome management rules and a centripetal programming approach. There appears little need to fear an excessively entrepreneurial Commission for some time to come.

Biographical note: Michael W. Bauer is Assistant Professor (C1) for Comparative Public Policy and Administration at the Department of Politics and Management, University of Konstanz, Germany.

Address for correspondence: Michael W. Bauer, Department of Politics and Management, University of Konstanz, D 91, D-78457 Konstanz, Germany. email: michael.w.bauer@uni-konstanz.de 


\section{ACKNOWLEDGEMENTS}

Earlier drafts of this paper were presented at the Connex RG1 Conference, 11-13 May 2006, Vienna, and at the EUSA Biannual Conference, 17-19 May 2007, Montreal. I am grateful for comments from Christoph Knill, Roger Levy, Liesbet Hooghe, Hussein Kassim and two anonymous referees. I am equally grateful for research assistance from Anna-Lena Beilschmidt, Dominik Bernauer, Michael Dobbins, Christina Eder, Elise Hadman, Dorota Tomalak, Jale Tosun, Natascha Warta, Stine Waibel und Alexander Wohlwender.

\section{NOTES}

1 This new system was designed to increase the transparency of individual performance assessment and to ensure unbiased transmission of these results to the superiors responsible for deciding about promotion. The appraisal system is hugely unpopular in the Commission. Its major deficiency seems to be that $\mathrm{HoU}$ shy away from giving a very high or a very low number of points (so the whole exercise becomes ineffectual). DG Administration is currently working on improving this system. The intention is to reduce the number of points that an individual can receive and create a 'normal' number of points for those who are doing a good, but normal job, which allows a normal career path without the current problem of comparative demotivation.

2 Explorative interview G, March 2005.

3 Explorative interview E, March 2005.

4 This interview was conducted in German; the term in the original is "Überzengungstäter'.

5 Explorative interview A, March 2005.

6 The HoU were given the options 'positive', 'negative' and 'irrelevant' and 'don't know/no answer'.

7 To be sure, while the part directly before the open question was about reform issues, two-thirds of the questions asked in the survey had nothing to do with the Kinnock reform.

8 I conducted two regression analyses. First, I computed a multivariate ordinary least square regression. For that reason, I constructed an additive index with the answers obtained from the HoU when asked: 'If you assess the impact of the recent internal modernization (i.e. the so-called Kinnock reforms) in the light of your own experience, which of the following statements can you agree with?' Second, I conducted logit regressions. Unfortunately, the model fit is in general very low.

9 Reform aversion of initiative-oriented DG: this hypothesis relates to the different tasks that the Commission has to perform. One can distinguish three categories of policy DGs: implementation-oriented (e.g. agriculture, fisheries, cohesion policy), adjudication-oriented (competition, internal market, services) and initiative-oriented (justice, freedom, security, health and consumer protection, the environment, education and culture). According to simple entrepreneurship logic, one should see the initiative-oriented as most affected by reform, and therefore the HoU from these DGs would be most critical about the inflicted changes. Idealism aversion: this relationship concerns the original reason to join the Commission. The more 'idealism' (usually associated with individual enthusiasm to help foster European integration) an individual expresses, the more likely it is that he or she sees the Commission as the creative pivotal actor embodying the 'European interest', and the more sceptical this individual might be that the Commission is changing into a managerial administration, as had been the outspoken 
objective of the Kinnock reforms (reform aversion from idealists for European integration). Private sector experience: according to this hypothesis, 'work experience' outside the Commission would make the HoU more open to the kind of change brought about by the Kinnock reform. Number of staff: furthermore, to what extent an individual $\mathrm{HoU}$ is affected by the Kinnock reform depends (in crucial respects) on the number of staff for whom he or she is responsible. The more staff, the greater the managerial responsibility and the higher the related administrative requirements (as regards individual target-setting, promotion procedures, reporting, etc.). Hence, one would expect that the more personnel a policy $\mathrm{HoU}$ has charge of, the more critical are seen to be the effects of the Kinnock reform (reform aversion because of huge staff responsibility). Leftist aversion: finally, new public management reforms are ideologically closer to liberal and conservative political points of view. Hence, managers with a leftist political conviction should display aversion to such 'marketizing' organizational change (reform distaste owing to leftist political conviction).

\section{REFERENCES}

Balint, T., Bauer, M.W. and Knill, C. (2008) 'Bureaucratic change in the European administrative space. The case of the European Commission', West European Politics 32 (1) (forthcoming).

Bauer, M.W. (2002) 'Limitations to agency control in EU policy-making - the Commission and the poverty programmes', Joumal of Common Market Studies $40(3): 381-400$.

Bauer, M.W. (2005) 'The European Commission', in P.M. van der Hoek (ed.), Handbook of Public Administration and Policy in the European Union, London and New York: Taylor \& Francis, pp. 149-76.

Bauer, M.W. (2006) 'Co-managing programme implementation: conceptualizing the European Commission's role in policy execution', Journal of European Public Policy 13(5): $717-35$.

Bauer, M.W. (2007) 'The politics of reforming the European Commission administration, in M.W. Bauer and C. Knill (eds), Management Reforms in International Organizations, Baden-Baden: Nomos, pp. 54-69.

Bearfield, N.D. (2004) 'Reforming the European Commission. Driving reform from the grassroots', Public Policy and Administration 19(5): 13-24.

Christiansen, T. (2006) 'The European Commission. The European executive between continuity and change', in J. Richardson (ed.), European Union: Power and Policymaking, London and New York: Routledge, pp. 99-117.

Cini, M. (1996) The European Commission. Leadership, Organization and Culture in the EU Administration, Manchester: Manchester University Press.

Cini, M. (2004) 'The reform of the European Commission; an ethical perspective', Public Policy and Administration 19(3): 42-54.

Cokins, G. (1996) Activity-based Cost Management. Making It Work, New York: McGraw-Hill.

Coombes, D. (1970) Politics and Bureaucracy in the European Community: A Portrait of the Commission of the EEC, London: George Allen \& Unwin.

Cram, L. (1993) 'Calling the tune without paying the piper? The role of the Commission in European Community social policy', Policy and Politics 21: 135-46.

European Commission (2004) Completing the Reform Mandate: Progress Report and Measures to be Implemented in 2004, COM (2004) 93 final, 2 February 2004, Brussels.

Héritier, A. (1997) Policy-making by subterfuge: interest accommodation, innovation and substitute democratic legitimation in Europe - perspectives from distinct policy areas', Journal of European Public Policy 4(2): 171-89. 
Hix, S. (2005) The Political System of the European Union, 2nd edn, Basingstoke: Palgrave.

Hooghe, L. (2001) The European Commission and the Integration of Europe. Images of Governance, Cambridge: Cambridge University Press.

Kassim, H. (2004a) 'A historic accomplishment. The Prodi Commission and administrative reform', in D.G. Dimitrakopoulos (ed.), The Changing European Commission, Manchester: Manchester University Press, pp. 33-63.

Kassim, H. (2004b) 'The Kinnock reforms in perspective: why reforming the Commission is an heroic, but thankless task', Public Policy and Administration 19(3): $25-41$.

Kassim, H. (2008) "Mission impossible", but mission accomplished: the Kinnock reforms and the European Commission', Journal of European Public Policy 15(5): $648-68$.

Kingdon, J.W. (1995) Agendas, Alternatives and Public Policies, New York: Longman.

Laffan, B. (1997) 'From policy entrepreneur to policy manager: the challenge facing the European Commission', Journal of European Public Policy 4(3): 422-38.

Levy, R. (2004) 'Between thetoric and reality. Implementing management reform in the European Commission', The International Journal of Public Sector Management 17: $166-77$.

Levy, R. (2006) 'European Commission overload and the pathology of management reform: garbage can, rationality and risk aversion', Public Administration 84(2): $423-39$.

Ludlow, P. (1991) 'The European Commission', in R.O. Keohane and S. Hoffmann (eds), The New European Community. Decision-making and Institutional Change, Boulder, CO: Westview Press, pp. 85-132.

Metcalfe, L. (2000) 'Reforming the Commission: will organizational efficiency produce effective governance?', Journal of Common Market Studies 38(5): 817-41.

Moravcsik, A. (1998) The Choice for Europe. Social Purpose and State Power from Messina to Maastricht, Ithaca, NY: Cornell University Press.

Noel, E. (1973) 'The Commission's power of initiative', Common Market Law Review 10: $123-36$.

Nugent, N. (ed.) (1997) At the Heart of the Union. Studies of the European Commission, Basingstoke: Macmillan.

Nugent, N. (2001) The European Commission, Basingstoke: Palgrave.

Peters, B.G. (1994) 'Agenda-setting in the European Community', Journal of European Public Policy 1(1): 9-26.

Peters, B.G. (1996) 'Agenda-setting in the European Union', in J. Richardson (ed.), European Union: Power and Policy-making, London and New York: Routledge, pp. $61-76$.

Peterson, J. (1995) 'Playing the transparency game: consultation and policy-making in the European Commission', Public Administration 73(3): 473-92.

Pollack, M.A. (2003) The Engines of European Integration: Delegation, Agency and Agenda Setting in the EU, Oxford: Oxford University Press.

Pollitt, C. and Bouckaert, G. (2004) Public Management Reform - A Comparative Analysis, Oxford: Oxford University Press.

Richardson, J. (2006) 'Policy-making in the EU. Interests, ideas and garbage cans of primeval soup', in J. Richardson (ed.), European Union. Power and Policy-making, London and New York: Routledge, pp. 3-29.

Rochefort, D.A. and Cobb, R.W. (eds) (1995) The Politics of Problem Definition: Shaping the Policy Agenda, Lawrence, KS: University Press of Kansas.

Sabatier, P.A. (1993) 'Advocacy-Koalitionen, Policy-Wandel und Policy-Lernen: Eine Alternative zur Phasenheuristik', in A. Héritier (ed.), Policy Analyse. Kritik und Neuorientierung, Opladen: Westdeutscher Verlag, pp. 116-48. 
Schön-Quinlivan, E. (2008) 'Implementing organizational change - the case of the Kinnock reforms', Journal of European Public Policy 15(5): 726-42.

Smyrl, M.E. (1998) 'When (and how) do the Commission's preferences matter?', Journal of Common Market Studies 36(1): 79-100.

Spence, D. (2000) 'Plus ça change, plus c'est la même chose? Attempting to reform the European Commission', Journal of European Public Policy $7(1): 1-25$.

Spence, D. (2006) 'The DGs and the services: structures, functions and procedures', in D.B. Spence and G. Edwards (eds), The European Commission, London: John Harper Publishing, pp. 128-55.

Spence, D. and Stevens, A. (2006) 'Staff and personnel policy in the Commission', in D.B. Spence and G. Edwards (eds), The European Commission, London: John Harper Publishing, pp. 173-208.

Stevens, H. and Stevens, A. (2006) 'The internal reform of the Commission', in D.B. Spence and G. Edwards (eds), The European Commission, London: John Harper Publishing, pp. 454-80. 